DOI: $10.23860 / J M L E-2019-11-2-5$

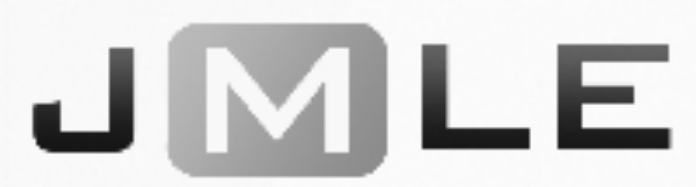

The National Association for Media Literacy Education's Journal of Media Literacy Education 11 (2), 79 - 94

\title{
Adolescents' Digital Literacies in Flux: Intersections of Voice, Empowerment, and Practices
}

\author{
Sandra Schamroth Abrams, Mary Beth Schaefer \& Daniel Ness \\ St. John's University, USA
}

\begin{abstract}
This article features a collaborative autoethnographic examination of three adolescent-researchers' digital literacies. The participatory design punctuates the role of the adolescent-researchers as they explored their meaning-making practices. Such collaborative research, which included three adolescents and their parents, not only resurfaces parent-inquiry, but also brings the adolescentresearcher voice to the forefront of literacy research. Two research questions guided the investigation: (a) What do adolescent-researchers tell us about their digital and nondigital literacy practices? and (b) In what ways do adolescent-researchers' retrospective examinations of their own practices reveal their perspectives of these practices and the power (and power struggles) that underlie them? The research team engaged in two rounds of coding, embracing first dramaturgical coding and then versus coding. Results suggested that Perspective/Attitude was the most prevalent attribute in the adolescent-researchers' discourse. Moreover, versus coding revealed strong relationships between "then versus now." Overall, the voices of the adolescent-researchers offer ongoing authenticity to discussions of their practices, creating continued opportunities to rethink the implications and applications of digital and nondigital practices in adolescents' lives.
\end{abstract}

Keywords: digital literacies, media literacies, participatory research, adolescent literacies

Nearly one century ago, Jean Piaget completed Origins of Intelligence in Children (originally published in French in 1936 and then in English in 1952), which details his examination of his own infant children in an effort to understand child development and cognition during the pre-semiotic sensorimotor period. Fast forward approximately one half a century, and scholars, such as Heath (1983) and Bissex (1980), initiated discourse about family literacies, paving the way for researchers to look not only within participants' homes, but also their own (Bissex, 1980). More recently, other researchers (Dezuanni, 2018; Kabuto, 2008; Long, 2004; McCarty, 2012; O'Mara \& Laidlaw, 2011; Yoon, 2012) followed suit examining their children's meaning making and contributing to the limited line of parent-researcher inquiry by offering nuanced understandings of literacies and learning. The present study adds yet another dimension to the existing literature on parent-researcher inquiry wherein adolescents are co-researchers. Such an approach affords the field a rich context and unique perspective for understanding 
these adolescent-researchers' shifting layers of literacies (Abrams, 2015, 2017). Thus, in this kind of participatory research, the adolescent-researchers themselves take up questions related to their own media literacies and position themselves not as participants, but as agents of study.

As researchers of their own digital and nondigital practices, three adolescent-researchers work with each other and their parent-researchers to explore and to explain how enhanced understandings of their own digital literacies figured in how they practice and play with those literacies. The adolescent-researchers' reflective practices provide a vista for the boundaries of who can be a researcher and afford unique perspectives on ways that adolescent-researchers develop and contextualize self-understandings of their literacies.

\section{DIGITAL LITERACIES}

We need to remember that social forces, and the technologies they produce, often define the changing nature of literacy today just as they have in the past. Clearly, the social forces in the present context will exert similar changes. Thus, attempts to develop any theory of literacy must begin by exploring the critical social forces at work today. (Leu, Kinzer, Coiro, Castek, \& Henry, 2017, p. 1)

The discussion of literacies in its plural form signals the importance of sociocultural experiences that shape one's interpretation of and interaction with multimodal texts and practices. In the earlier quotation, Leu et al.'s concern about social forces and technologies underscores the intricate and inherent relationship between social norms and practices and the use and (re)development of technologies. When discussing digital literacies and media literacies, there are important factors to consider regarding the use of and interaction with digital resources - access, communication competencies, creation and analysis of content, and a greater application of critical and socially responsible understandings (Hobbs, 2010; Hobbs \& Moore, 2013). These points are subsumed by the "umbrella concept" (Koltay, 2011) of digital and media literacies "characterized by a diversity of perspectives and a multitude of definitions" (p. 212). Where the idea of media as a literacy departs from digital literacies is in its positioning in much of the literature. Media literacy, as described and defined by Bawden (2008), implies an ability to deal with information formats that are "'pushed' at the user" (p. 30). In light of the different positionings and perspectives, Koltay's (2011) suggestion is interesting and compelling: "Media literacy thus has to find its role both in primary, secondary and higher education either on its own, or presumably - with more likelihood - as part of some kind of multiple or multimodal literacy" (p. 219).

Similarly, with regard to digital literacies, Lankshear and Knobel (2008) acknowledged the "plethora of conceptions of digital literacies," and the importance of "emphasiz[ing] the plurality of digital literacies" to accommodate the range of definitions and the sociocultural view of literacies (p. 2). Therefore, when discussing digital literacies, it is important to account for a variety of definitions, including, but not limited to, those that specifically attend to 
information literacy, online interaction, and navigation across non-linear, hyperlinked spaces (Jones-Kavalier \& Flannigan, 2006). These calls are especially compelling when one acknowledges the central commonalities among digital and media literacies: Both represent a range of practices and skills, and both are in flux. The central definitions of media literacy and digital literacy change in response to what Forzani and Leu (2017) describe as the "constantly evolving" social context in which both literacies live (p. 19).

In this article, similar to Lankshear and Knobel (2015), the research team considers the plurality of the term, "literacies", and its sociocultural roots that signal an important departure from a tether to alphabetic text to an acknowledgement of a more expansive conception of literacies - one that embraces the importance of examining experience, multimodalities, and meaning making (New London Group, 1996; Street, 1995). Attempting, therefore, to distill a theory or concept of literacies from current research where constants are ephemeral is rather like attempting to grab and hold onto jello as it slides from the hand and winds up elsewhere. This present research is one attempt to describe the jello in mid-slide and from the perspective of adolescent-researchers - the primary movers, creators, and users of digital and media literacies. The focus here on digital literacies acknowledges its range of practices and definitions with media literacy embedded within those practices and definitions. Thus, the ethos of Lankshear and Knobel's (2015) point resounds:

digital literacy [is] not...something unitary, and certainly not...some finite competency or skill —or even...a set of competencies or skills. Rather it means we should think of digital literacy as shorthand for the myriad social practices and conceptions of engaging in meaning making mediated by texts that are produced, received, distributed, exchanged etc., via digital codification. Digital literacy is really digital literacies. (p. 13, emphases in original)

Building upon this understanding of digital literacies, the research team examined digital literacy practices, looking to the word, practices, to call specific attention to the various activities and resources that are part of the adolescent-researchers' overall values and meaning-making experiences.

Furthermore, for the purpose and scope of the examination of digital and nondigital practices, the term, digital literacies, denotes meaning making in, with, and across digital spaces and resources. Such meaning making helps to reveal ways that adolescents adopt, perceive, and sometimes push against social norms that may or may not include the use of digital devices. Even though the digital and nondigital are discussed separately in this article, they are not conceptually dichotomized with regard to meaning making because the lines between digital and nondigital, and online and offline, often are blurred (Burnett \& Merchant, 2014), and practices and values in one space inherently inform the other.

Therefore, when the research team addresses digital and nondigital practices, the concern is not specifically what devices the adolescent-researchers are using or how the adolescent-researchers are responding to the information they encounter online (although both are points to consider at another time). Rather, for this investigation, the research team-three adults and three adolescents working 
as co-researchers - question how and why do digital and nondigital resources figure into the three adolescent-researchers' lives and in what ways does such an investigation reveal any critical challenges related to those practices.

\section{CONCEPTUAL FRAMEWORK}

This research, which hinges on adolescents and their parents collaboratively researching adolescent literacy practices, is conceptually grounded in critical dialectical pluralism, a form of participatory research that underscores the integral involvement of the participant-as-co-researcher and helps to flatten conventional hierarchies associated with researcher-driven decisions related to a study's design, data collection and analysis, and dissemination of findings (Onwuegbuzie \& Frels, 2013). Typically, critical dialectical pluralism involves a progressive perspective of participatory research and focuses on the inclusion of the participant in the research, the emergence of participants' voices, and the mitigation of researcher bias (Abrams et al., 2017; Gerber et al., 2017; Johnson \& Onwuegbuzie, 2004; Ness et al., 2018; Schaefer et al. 2018). More specifically, this approach involves

empowering the participants to make research-based decisions at the various stages of the research process (i.e., research conceptualization, research planning, research implementation, research utilization)...[and] assume the role of participant-researchers, who, subsequently, either perform or present the findings themselves. (Onwuegbuzie \& Frels, 2013, p. 15)

Overall, critical dialectical pluralism extends participatory research to the boundaries of design in that the participants, to the best of their ability and willingness, become co-researchers. Furthermore, a critical dialectical pluralist lens offers an innovative approach to participatory research in that the youth are intricately and inherently central to conducting and analyzing the data at all phases of inquiry (Onwuegbuzie \& Frels, 2013). This conceptual frame informs the research team's ethical perspectives as the adolescent-researchers work with parent- and adult-researchers to co-examine and self-reflect upon their digital and nondigital practices.

In this study, the research team is confronted with two existing hierarchical structures - that of parents and that of education researchers - and a critical dialectical pluralist philosophy gives credence to the research team's epistemological, ontological, and methodological stance. After all, the purpose of the co-investigation is to understand better the adolescent-researchers' practices as they see them and not as their parent-researchers perceive. Furthermore, a critical dialectical pluralist frame empowers the adolescent-researchers to participate how and when they want to, and a collaborative autoethnographic research design enables the parent-researchers to co-participate in the research with their adolescent children.

\section{RESEARCH DESIGN}


This study embraces a collaborative autoethnographic research design (Chang, Ngunjiri, \& Hernandez, 2013), which helps to elicit equal input from all researchers. A collaborative autoethnography is a form of inquiry that involves "engaging in the study of self, collectively; it is a process and product of an ensemble of performance, not a solo act" (Chang et al., 2013, p. 11). The six research team members - three adolescents and three adults - engaged in individual and collaborative data collection and analyses, and "the combination of multiple voices to interrogate a social phenomenon create[d] a unique synergy and harmony that autoethnographers cannot attain in isolation" (Chang et al., 2013, p. 24). Although the research team often met as a collective group of six, the adolescent-researchers also met in digital and nondigital spaces without the adults (and vice versa), and each parent-researcher contributed to the research individually as well. This was possible because collaborative autoethnographies honor the emergence of individual voices while supporting the strength of the collective.

In other words, the collaborative autoethnographic approach is not solely about sharing insights and negotiating meeting. It also supports, and in this case, involves, a democratic, critical dialectical pluralistic foundation that helps to reduce researcher-participant hierarchies, support multiple interpretations, and confront dominant narratives. This study provides insight into the thoughts and practices of the three adolescent-researchers, supports youth engaging in self- and collaborative study, and advances education research by offering layered perspectives of meaning making.

\section{METHODS}

The research presented in this article initially stemmed from conversations between the adolescent-researchers and their parent-researchers, and the investigation developed because of a shared interest in learning more about youth practices in the digital age and the adolescent-researchers' interest in exploring their perspectives and activities. As such, the three adolescent-researchers partook in participatory investigations and engaged in collaborative autoethnographic writing (Chang et al., 2013), "an iterative and social process that involves a team focused on a common objective that negotiates, coordinates, and communicates during the creation of a common document" (Lowry, Curtis, \& Lowry, 2004, p. 72; Chang et al., 2013, p. 118).

The investigation began with the adolescent-researchers' interest in exploring their practices, and with the development of two guiding research questions:

1. What do adolescent-researchers say about their digital and nondigital literacy practices?

2. In what ways do adolescent-researchers' retrospective examinations of their own practices reveal their perspectives of these practices and the power (and power struggles) that underlie them? 
These questions supported the emergence of youth voices and framed the examination from the perspective of the adolescent-researcher and of the parentresearcher. A critical dialectical pluralistic stance emphasized the importance for all to

have a co-equal say in what phenomenon should be studied; how research should be conducted to study this phenomenon; which methods should be used; which findings are valid, acceptable, and meaningful; how the findings are to be disseminated and utilized; and how the consequences of such decisions and actions are to be assessed. (Onwuegbuzie \& Frels, 2013, p. 15)

Although there were clear moments of collaboration and introspection, there were two factors that became more evident as the research team engaged in the collaborative autoethnography: (a) the adolescents were novice researchers and needed to learn how to engage in autoethnographic writing, and (b) the research team shared an emtic perspective (Onwuegbuzie, 2012) because the parentresearchers and adolescent-researchers simultaneously were insiders and outsiders as they worked with familiar and unfamiliar research team members; this dynamic offered insight into undeveloped responses and shaped the way each researcher interpreted the data. The research team attended to the first concern by working collaboratively. Specifically, adult-researchers offered initial prompts and honored an open space for the adolescent-researchers to develop their own writing and voice their own thoughts and concerns. Additionally, the adolescent-researchers successfully completed the NIH-sponsored Human Research Participants training (e.g., each holds his/her own certification) and, thus, engaged in many of the same practices as did the adult researchers. Per the second concern, the emtic perspective was both an affordance and constraint of parent-child research. Not only did the research team use researcher memos to document bias and prior knowledge, but also they collaborated in various capacities: adolescent-researchers worked with each other and with parent- or other adult-researchers, as well as part of the sixperson collective team. This format helped to mitigate biases and to maintain a rigor that strengthened the overall investigation.

Aware of the inevitable "exercise of power" that occurs when ethnographers analyze and report data (Wolf, 1992), the research team embraced the powersharing inherent in collaborative autoethnography (Chang et al., 2013). The parents-as-education-researchers recognized that their knowledge of research and of the field positioned them as the formal crafters of the research questions and this article; however, with the reflective rigor required by qualitative inquiry, the adultresearchers not only acknowledged this positioning, but also worked to mitigate other issues of power by collectively analyzing data, brainstorming the manuscript with the adolescent-researchers, and collaborating with the adolescent-researchers to confirm, to challenge, and/or to clarify written documentation. Additionally, the use of Google Docs offered the adolescent-researchers a forum that supported asynchronous writing and peer review. Google Docs provided a space for the adolescent-researchers to respond to adult- and adolescent-designed prompts; maintain informal reflective memos; provide each other feedback; and engage in 
data analyses. The research team focused on precision and detail, and they used thick, rich description (Geertz, 1973; Ryle, 1949, 1971) when identifying and interpreting human behaviors. Furthermore, the collaborative autoethnographic study (Chang et al., 2013) specifically attended to power issues because the research design "deliberately and explicitly emphasizes collaboration at every point in the ethnographic process, without veiling it" (Lassiter, 2005, p.16, emphasis in original). Although the findings section features each adolescent-researcher's initial (instead of his/her full name), this was a purposeful and deliberate decision that the research team made together and yet another example of the transparency and collaboration inherent in such a collaborative autoethnographic, critical dialectical pluralist study. Overall, the adolescent-researchers were sensitive and responsive to both individual and group intentions and, therefore, advanced the authenticity of the phenomenon under examination.

\section{Participants}

This research involves six participant-researchers: three adolescents, who are in the middle and high school years, and their respective middle-aged parents, who are educators and education researchers. As such, the research team comes from a position of educational privilege. All live in the northeastern United States. $\mathrm{C}$ is a 14-year-old girl who lives in a suburban area close to a state border and attends middle school at an internationally diverse school 30 miles from a major US city. $C$ enjoys reading and drawing, and she is a member of various sports teams. $\mathrm{C}$ plays videogames and follows friends on Instagram. $\mathrm{M}$ is a 15-year old girl who lives in an urban community and attends high school in an urban-intensive (Milner, 2012) area. She is a competitive dancer, is interested in all things related to animals; and enjoys long walks in her urban community. $\mathrm{E}$ is a 15 -year-old boy who lives in a suburban area and attends a public high school just on the outskirts of a very large metropolitan area. An avid musician, he has played piano since he was three years old and cello since he was seven. He currently is extremely competitive in his music performance. When he was eight years of age, he selected fencing as his sport. E still fences because all of his friends play other sports and he wants to establish his uniqueness. More than 52 miles separate the research team, and the adolescentresearchers did not know each other prior to this research endeavor. Nonetheless, they have come to know one another through various interactions, including, but not limited to, face-to-face and online research team meetings, group texting, presentations at professional conferences, and informal game play.

For almost two years, all six researchers co-investigated youth digital and nondigital practices; this involved the adolescent-researchers discussingindividually and collectively with their parents and other research team memberswhat they did online and offline. The adolescent-researchers self-selected and shared examples of their practices and preferences. In essence, they reflected aloud and on paper about what they did, and their parents-as-co-researchers reflected on the process, too, and the six-person research team shared their noticings with one another.

\section{Data Collection and Analysis}


The collaborative autoethnography involved iterative processes that included three rounds of data collection, as well as personal and group reflection, exploration, sharing, data (re)evaluation and analysis, and writing (Chang et al., 2013). Given the physical distance that separated the research team and the constraints of collective school and extracurricular schedules, the research team used Google Docs and Google Hangout as a free and accessible communication platform to support synchronous and asynchronous data collection, data analysis, and research team meetings.

The first round of data collection featured the adolescent-researchers on Google Docs writing about their digital and nondigital practices, and they used the comments feature to inquire about each other's practices, opinions, and interests. Two Google Hangout videoconferences, which involved all six co-researchers, extended conversations initiated in the written dialogue and addressed emerging themes. Although initial discussions were led by the parent-researchers who have had experience with data coding and analysis, the adolescent-researchers partook in ongoing analyses when addressing the similarities and differences among their posts, as well as what stood out for them when reviewing the data.

The second round of data collection had similar features to the first, but it primarily focused on the adolescent-researchers' use of images to characterize their digital and nondigital practices and preferences. The use of images supported a flattening of hierarchies because the adolescent-researchers led this iteration of data collection; they self-selected images, engaged in discussions and explanations of the images, and talked about the areas of convergence and divergence in their collective practices. Having noticed how well this approach worked as a data collection and initial analysis tool, the six research team members contemplated how group texting might support ongoing research discussions. Thus, the adolescent-researchers also engaged in a group text about their practices, and, although there was initial success, group texting was an activity that was short lived because of summer camp activities that removed electronic communication from the equation. Nonetheless, the images and the texting helped the adolescentresearchers to explain their understandings to the research team, and the multimodal representations of their literacies informed the adolescent-researchers' creation of a professional presentation. Similar to the first round of data collection, this round extended initial conversations and supported the generation of formal, written reflections.

The third round of data collection involved the adolescent-researchers examining the research to date-the collection of their written memos, their peer feedback, their images, and their presentation materials. The adolescent-researchers then constructed reflective memos wherein they examined the practices they noted during the previous two rounds of data collection. At that point, the six research team members reviewed the written reflections and engaged in informal, preliminary data "themeing" (Saldaña, 2016), which involved using "an extended phrase or sentence [to identify] what a unit of data is about and/or what it means" (Saldaña, 2016, p. 199, emphases in original). This approach not only was a precursor to the overall data analysis that informed this manuscript, but also it 
encouraged the emergence of youth voice and participation and enabled the emergence and refinement of codes over time.

Engaging in collaborative coding helped us as a team to explore larger categories of understanding related to the adolescent-researchers' developing selves and their negotiation of digital literacies. The adolescent-researchers conversed with each other, individually with their parent-researcher, with the other adult-researchers, and with the research team collective. The six researchers maintained reflective memos and looked to clarify, confirm, and challenge assumptions, develop and discuss findings, and address issues of power and bias.

Despite initial rounds of data themeing, the research team was at an impasse. Each person struggled to categorize the themes possibly because of his/her proximity to the data. Therefore, the six researchers engaged in two formal rounds of coding, embracing first dramaturgical coding and then versus coding (Saldaña, 2016; Saldaña \& Omasta, 2018). Dramaturgical coding is rooted in Goffman's (1959) examination of social norms and identity performances and "can reflect a participant's needs and wants" (Saldaña, 2016, p. 150). Dramaturgical coding specifically involves six codes-motives/objectives (OBJ), conflicts or obstacles $(\mathrm{CON})$, strategies or tactics (TAC), perspectives or attitudes (ATT), emotions expressed/experienced (EMO), and underlying, unspoken responses or subtexts (SUB) - and works well with collaborative autoethnographic accounts because such coding attends to "naturalistic social interaction or...a participant's stories" (Saldaña \& Omatsa, 2018, p. 219). The six researchers did not find the final code (i.e., SUB) useful in the case of a collaborative autoethnography because each researcher explored his/her own "internal perspectives" (Saldaña, 2016, p. 148), and the research team envisioned potential ethical concerns if any of the six researchers made inferences about the overt reflections. Furthermore, the research team used member checking as a way to discuss (mis)interpretations and offer clarifications. When engaging in member checking, the adolescent-researchers confirmed some codes and changed others, offering explanations for such modifications that, in turn, also became data points.

The use of dramaturgical codes yielded insights into the nuances of the adolescent-researchers' relationship with self and literacies. The codes for Emotion, Tactics, Objectives, and Conflicts were approximately even across the transcripts. Similar to Onwuegbuzie, Frels, and Hwang (2016), the research team found Perspective/Attitude to be a pervasive code, appearing $25 \%$ more often than the other codes, and when the researchers took a closer look into the data coded for Perspective/Attitude, the team members could see clearly the adolescentresearchers' expressions and proclamations of power, control, and selfunderstanding. Perspective/Attitude became the overarching theme for the adolescent-researchers' voices.

Even though dramaturgical coding turned out to be successful when interpreting the data, the research team perceived a number of dichotomies surfacing. Therefore, the six researchers looked to versus coding to tease out some of the layers underneath the adolescent-researchers proclamations and assertions. More specifically, versus coding involved coding "in binary or dichotomous terms two opposing stances" (Saldaña \& Omasta, 2018, p. 222). Versus coding revealed 
tensions, such as "then versus now," "what others do versus what I do," "what makes us happy versus unhappy," and "using devices versus not using them." Such an approach brought to light the shifts in the adolescent-researchers' perspectives and underscored how their digital literacies were in flux. Looking across the themes and codes, the research team located the pulses of these negotiations with digital literacies.

\section{FINDINGS}

Reflecting on their literacy practices for almost two years yielded important insights into the adolescent-researchers' thinking about literacies and, thus, about themselves. They investigated alone, with each other, and with the parentresearchers. Together, the research team found rich reflective practices that gave the adolescent-researchers insights into the complex and sometimes fraught relationship they had with digital literacies.

The findings are arranged into categories that represent the essence of the adolescent-researchers' negotiation with digital and nondigital practices. The adolescent-researchers" "Perspective/Attitude" is suffused with emotions and strategies noted in the other codes and informed by the conflicts noted in the versus coding. The findings help illuminate the push and pull of the adolescentresearchers' experiences with digital literacies as explored throughout the study period. These forces may be characterized by Push and Pull, Change, and Power, and each is described in the following sections.

\section{Push and Pull: "I put minimal effort into trying to pry myself from the dark hole of the Internet." (M)}

The adolescent-researchers' retrospective examination of their digital and nondigital practices illustrated a keen understanding of the forces of playparticularly play with digital forces. However, the three adolescent-researchers experienced the allurement of digital literacies in very different ways. $\mathrm{C}$ understood the attraction and affordances of digital literacies. Although not all-consuming, playing videogames was very much a part of her digital literacies. She noted that while a couple of years ago, "everything was about Minecraft," her current digital practices did not regularly include playing videogames due to her academic and athletic responsibilities. C explained, "I have not been able to play videogames as often because I am doing homework or going to practices for my current sport." Additionally, the social affordances of digital literacies became more attractive to C. She noted that, even with videogaming, "Everything I do digitally is very social." Even though $\mathrm{C}$ actively followed an artist on Instagram, she talked of ways that she pushed away from the digital world when she desired a "place of quiet" to do things like "art or reading," activities that, for C, involved a pencil or a paperback novel. M's experience with the pull of digital practices was more encompassing and pressing. She looked back at her digital and school activities and lamented, "I never really stopped to look around and enjoy the good life." This seems to be a result of time constraints; $M$ did not have time for school and videogames. Rather, it was an either/or situation. Her intense focus on school impinged on her desire to play 
videogames - and when she did engage in videogames, she found herself so deeply engaged that "I barely had time to do any homework." E noticed this seduction among his peers in school and rejected the pull of the digital world to the extent that the pull became a push. He noted, "Sole focus on digital devices might just be the death knell of society." While presenting different experiences with digital technologies, all three seemed aware of ways that the temptations of technology could loom too largely over other activities, and this understanding seemed to have helped them to recognize the pull of videogames and social media and negotiate accordingly.

\section{Change: "I am a different person now." (C)}

Re-examining their digital literacies appeared to afford the adolescentresearchers a vivid glimpse into the ways that they had changed vis-à-vis digital and nondigital practices. E's change was pointedly focused on his nondigital achievements. He noted, "I think I have progressively developed over the last few years. I think my cello and piano playing improved." Perhaps more importantly, he noted that the research on digital literacies helped him to think about how his beliefs "have either changed or remained the same." M noticed that while there was some change in her activities, what mattered to her was how she engaged with them. M purposely used the word, "exploded," to capture the passion in her realizations: "I exploded how I interacted with playing the piano, competitive dancing, and playing PC games...the rough idea of these main topics stayed constant...but the way I interacted with them changed." She explained how she became more focused on honing her practices, be they online or offline. Putting energy into competitive dancing helped her become "one of the forces to be reckoned with." M also noted a change in the how she engaged in digital practices: "I do not use my digital time for social media as much anymore. I still text my friends, but I usually do that for homework or when I am bored. I mainly use my phone for relaxing purposes." C's sense of change emerged when she looked over the visual data. She expressed a kind of disconnect between her younger and current self. Specifically, after reviewing the images of her activities that she had previously selected (see Figure 1), she wrote, "I think that the images are a little inaccurate, however, that could just be because I'm a different person now." She noted that the images she used to illustrate her activities were "not actually of me doing my practice." Rather, they were stock photo images. The effect was that $\mathrm{C}$ found her past representations of her practices neither accurate nor relatable. Although $\mathrm{C}$ was still interested in playing sports and painting, she realized that her self-selected images actually were generalized representations of activities and not specific identifiers of her engagement in particular practices. C's discomfort with the images helped her to recognize changes in her interests and activities - and in herself. 


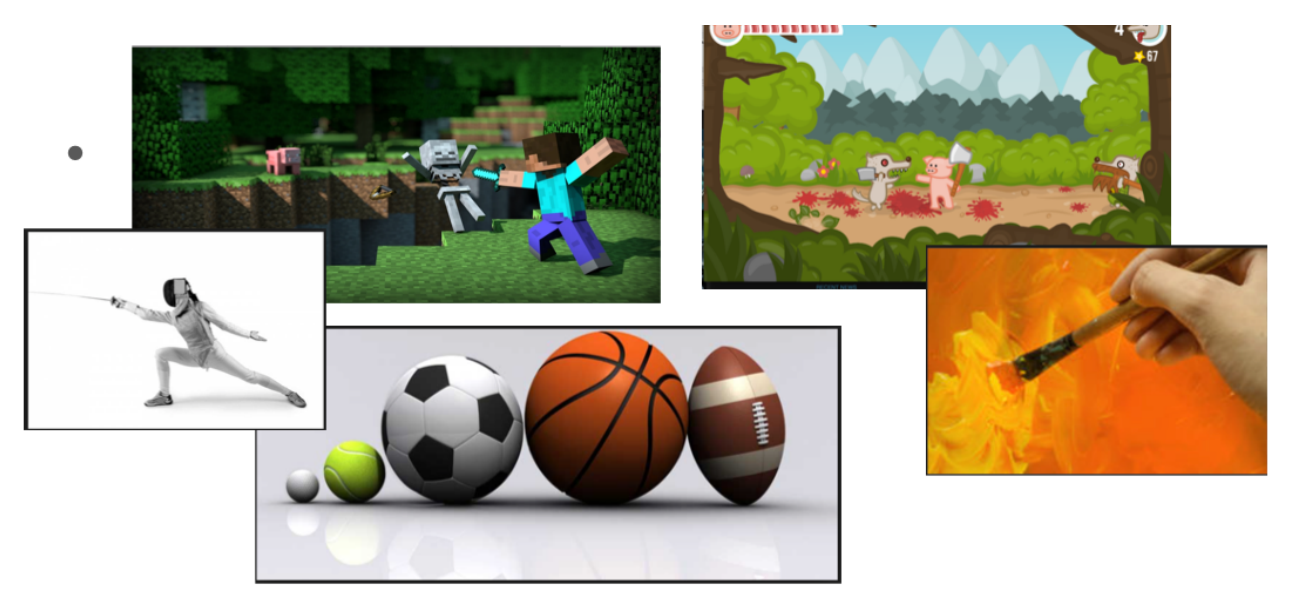

Figure 1. C's initial representations of her digital and nondigital practices.

\section{Power: "I guess I'm a rebel against people who overuse digital technology."} (E)

Awareness of their own digital practices seemed to give all three adolescentresearchers a sense of power and control. They expressed confidence in their own understandings of change and of their interactions with digital literacies. Their assertions about their self-discoveries exuded optimism and confidence. M's confidence came through as she described how she put digital practices "in their place". After lamenting that her forays into YouTube and other enticements of the "dark hole" of the Internet created anxiety over managing her time, she wrote, "I developed an efficient way for getting school work done that...has freed up more time for me so that I can hang out with my friends." She also managed the affordances of digital technology to help her socially:

Because I still socialize with my friends a lot digitally (Facetime calls, sending memes, texting homework, etc), digital activities still play an important role in my life. Through these digital experiences, I can learn many things, such as what I mean to people, how I express myself, and what I can do to make myself a better person.

E's confidence was seen in his plans to build on his progress with his offline activities. His short-term plans included joining the school fencing team and traveling to Italy with his Italian class, and his long-term plans included using his "experiences in music and possibly science or neuroscience when I get to college." $\mathrm{C}$ asserted power over her literacy practices and drew understanding from those practices: "Most of my digital activities have to do with connecting with people...It is a part of me in that I take enjoyment in my online activities but also because it can shape what kind of person I am." Taking power and control over that shape, C believed she could also help to form her own future.

\section{DISCUSSION}

In a recent article about digital literacies, Elena Forzani and Donald Leu (2017) wondered how the literacy community can fully appreciate the continual changes to literacies "where the object that we study is continually changing" ( $p$. 
19). The findings in this current study reveal the pulses of change and illuminate what change looks like from the perspective of three adolescent-researchers as they examined their literacy practices and continued their journey in and through adolescence. In the adolescent-researchers' understandings of their own literacies, the research team found powerful intersections of voice and control. The adolescent-researchers not only had confidence in their own futures, but also expressed perseverance and tenacity in terms of their goals in their digital and nondigital experiences.

Another overarching theme that permeated the lives of the three adolescentresearchers in this study was attitude about what one should do and how one should go about their everyday digital practices. Given his seemingly sardonic attitude toward digital technologies, E demonstrated a powerful world view regarding not what these technologies have to offer, but how these technologies were used in everyday life. Although he was almost entirely steadfast in his opinion, E argued for the use of digital technologies as a means to an end and not an end per se. M's attitude seemed to intersect with E's in that she argued in favor of digital literacies as a means to complete various projects in order to engage in more time with friends. For C, digital use was associated with the lack of calmness and repose. Her view was that quiet time might require the surrender of digital devices.

One can also appreciate the element of resistance within the dicta of the three adolescent-researchers. In essence, resistance can occur as a struggle to change or to shift particular paradigms in a way that revolutionizes our everyday lives; such resistance highlights difference and uniqueness in terms of identity and self-reflection related to various digital and nondigital experiences. For the most part, the three adolescent-researchers demonstrated the latter form of resistance (i.e., E revealed his version of resistance through his pride in not always engaging in smartphone activities like most of his classmates). Moreover, the three adolescent-researchers' notion of change through the ongoing research process revealed individualized forms of resistance. In connection with this notion of resistance is the progressive transition from a generally unsystematic approach to digital use to a more focused one. This was evidenced by M's gradual prioritization of and emphasis on her competitive dancing, an activity in which she referred to herself as "one of the forces to be reckoned with."

It is also interesting to note that given the three adolescent-researchers' views that their interests in both digital and nondigital practices changed over time, they perceived these focused changes and contemplated how their schedules could be better organized. Just as younger children transition out of dramatic play or constructive free play with blocks and bricks, so, too, did the adolescent-researchers modify and adjust their digital and nondigital penchants in ways that accommodated how they carried out their activities and organized their time. Evidence of greater focus for the purpose of time and space organization was demonstrated when $\mathrm{C}$ noted that in the first year of the research, "everything was about Minecraft" and that her current digital practices have evolved due to her school responsibilities and social life. 


\section{Conclusion}

Research that is rooted in critical dialectical pluralism supports the empowerment of youth (in this case adolescent-researchers), the emergence of their voices, and an introspective view of their practices. This study, which hinged on the role of the adolescent-researcher, offers insight into the ways digital literacies are constantly in flux and influenced by social and developmental changes. As the three adolescent-researchers' insights revealed, the state of becoming includes the revision, the refinement, and the reaffirmation of digital and nondigital literacy practices.

Additionally, the approach presented in this article opens new pathways for "entering" the minds of children and adolescents (Ginsburg, 1997) and supporting their engagement in the same or similar endeavors as their researcher parents or guardians. These pathways have the potential to shed new light and perspective on a given topic of inquiry - light that might otherwise be overlooked through traditional research models. Moreover, the methodological approach used in this article is one that might enable teachers to rethink what it means for adolescents to be researchers. Adolescent-researchers can do more than simply follow curricular scripts about what it means to collect information and build reference lists; they also can reflect upon and examine their own ways of knowing and doing things digitally and nondigitally that build upon what it means to be a researcher. In so doing, adolescent-researchers can be instrumental visionaries and agents of change.

\section{REFERENCES}

Abrams, S. S. (2015). Integrating virtual and traditional learning in 6-12 classrooms: A layered literacies approach to multimodal meaning making. New York: Routledge.

Abrams, S. S. (2017). Emotionally crafted experiences: Layering literacies in Minecraft. The Reading Teacher, 70(4), 501-506.

Abrams, S., Schaefer, M., Ness, D., Abrams, C., Kurpis, M., \& Ness, E. (2017, February). Children as co-researchers of their digital activities. Paper presented at the 38th Annual Ethnography in Education Research Forum, University of Pennsylvania, Philadelphia, PA.

Bawden, D. (2008). Origins and concepts of digital literacies. In C. Lankshear \& M. Knobel (Eds.), Digital literacies: Concepts, policies and practices (pp. 17-32). New York, NY: Peter Lang.

Bissex, G. L. (1980). Gnys at wrk: A child learns to read and write. Cambridge, MA: Harvard University Press.

Burnett, C., \& Merchant, G. (2014). Points of view: Reconceptualising literacies through an exploration of adult and child interactions in a virtual world. Journal of Research in Reading, 37(1), 36-50.

Chang, H., Ngunjiri, F., \& Hernandez, K. A. C. (2013). Collaborative autoethnography. New York, NY: Routledge.

Dezuanni, M. (2018). Minecraft and children's digital making: Implications for media literacy education. Learning, Media and Technology, 43(3), 236249 . 
Forzani, E., \& Leu, D. J. (2017). Multiple perspectives on literacy as it continuously changes: Reflections on opportunities and challenges when literacy is deictic. Journal of Education, 197(2), 19-24.

Geertz, C. (1973). The interpretation of cultures. New York, NY: Basic Books.

Ginsburg, H. (1997). Entering the child's mind: The clinical interview in psychological research and practice. New York, NY: Cambridge University Press.

Goffman, E. (1959). The presentation of self in everyday life. New York, NY: Anchor Books.

Heath, S. B. (1983). Ways with words: Language, life, and work in communities and classrooms. Cambridge, England: Cambridge University Press.

Hobbs, R. (2010). Digital and media literacy: A plan of action. [White paper]. Retrieved from https://files.eric.ed.gov/fulltext/ED523244.pdf

Hobbs, R., \& Moore, D.C. (2013). Discovering media literacy: Teaching digital media and popular culture in elementary school. Thousand Oaks, CA: Corwin.

Johnson, R. B., \& Onwuegbuzie, A.J. (2004). Mixed methods research: A research paradigm whose time has come. Educational Researcher, 33(7), 14-26.

Jones-Kavalier, B., \& Flannigan, S. L. (2006). Connecting the digital dots: Literacy of the 21st century. Educause Quarterly Magazine, 29(2), 8-10.

Kabuto, B. (2008). Parent-research as a process of inquiry: An ethnographic perspective. Ethnography and Education, 3(2), 177-194.

Koltay, T. (2011). The media and the literacies: Media literacy, information literacy, digital literacy. Media, Culture \& Society, 33(2), 211-221.

Lankshear, C., \& Knobel, M. (2008). Introduction. In C. Lankshear \& M. Knobel (Eds.), Digital literacies: Concepts, policies, and practices (pp. 1-16).

New York, NY: Peter Lang.

Lankshear, C., \& Knobel, M. (2015). Digital literacy and digital literacies: Policy, pedagogy and research considerations for education. Nordic Journal of Digital Literacy, 10, 8-20.

Lassiter, L. E. (2005). The Chicago guide to collaborative ethnography. Chicago, IL: University of Chicago Press.

Leu, D. J., Kinzer, C. K., Coiro, J., Castek, J., \& Henry, L. A. (2017). New literacies: A dual-level theory of the changing nature of literacy, instruction, and assessment. Journal of Education, 197(2), 1-18. (Reprinted from Theoretical Models and Processes of Reading, 6th Ed., 2013, International Reading Association).

Long, S. (2004). Passionless text and phonics first: Through a child's eyes. Language Arts, 81(5), 417-426.

Lowry, P.B., Curtis, A., \& Lowry, M.R. (2004). Building a taxonomy and nomenclature of collaborative writing to improve interdisciplinary research. Journal of Business Communication, 4(1), 66-99.

McCarty, G. M. (2012). Family science: An ethnographic case study of the ordinary science and literacy experiences of one family (Doctoral dissertation). Retrieved from https://irl.umsl.edu/dissertation/332 
Milner, H. R. (2012). But what is urban education? Urban Education, 47(3), 556561.

Ness, D., Schaefer, M., Abrams, S., Ness, E., Kurpis, M., \& Abrams, A. (2018 May). Rethinking Piaget and adolescent intellectual development through play: Adolescent co-researchers examine multimodal digital activities. Jean Piaget Society Conference, Amsterdam, The Netherlands.

New London Group. (1996). A pedagogy of multiliteracies: Designing social futures. Harvard Educational Review, 66(1), 60-93.

O'Mara, J., \& Laidlaw, L. (2011). Living in the iWorld: Two literacy researchers reflect on the changing texts and literacy practices of childhood. English Teaching: Practice and Critique, 10(4), 149-159.

Onwuegbuzie, A. J. (2012). Introduction: Putting the mixed back into quantitative and qualitative research in educational research and beyond: Moving towards the radical middle. International Journal of Multiple Research Approaches, 6(3), 192-219.

Onwuegbuzie, A. J., \& Frels, R. K. (2013). Introduction: Towards a new research philosophy for addressing social justice issues: Critical dialectical pluralism 1.0. International Journal of Multiple Research Approaches, 7(1), 9-26.

Onwuegbuzie, A. J., Frels, R. K., \& Hwang, E. (2016). Mapping Saldaña's coding methods onto the literature review process. Journal of Educational Issues, 2(1), 130-150.

Piaget, J. (1952). The origins of intelligence in children. M. Cook (Trans.). New York, NY: International Universities Press.

Ryle, G. (1949). Concept of the mind. London, England: Hutchinson and Company. Ryle, G. (1971). Collected papers. Volume II collected essays, 1929-1968. London, England: Hutchinson.

Saldaña, J. (2016). The coding manual for qualitative researchers (3rd ed.). Thousand Oaks, CA: Sage.

Schaefer, M.B., Abrams, S.S., Ness, D., Kurpis, M., Abrams, C., \& Ness, E. (2018, Oct). What middle grades students discovered while researching with parents. Annual Conference for Middle Level Education, Orlando, FL.

Saldaña, J., \& Omasta, M. (2018). Qualitative research: Analyzing life. Thousand Oaks, CA: Sage.

Street, B. (1995). Social literacies: Critical approaches to literacy, in development, ethnography and education. London, England: Longman.

Wolf, M. (1992). A thrice-told tale: Feminism, postmodernism and ethnographic responsibility. Stanford, CA: Stanford University Press.

Yoon, B. (2012). Junsuk and Junhyuck: Adolescent immigrants' educational journey to success and identity negotiation. American Educational Research Journal, 49(5), 971-1002. 